\title{
The paracrine effect of exogenous growth hormone alleviates dysmorphogenesis caused by tbx5 deficiency in zebrafish (Danio rerio) embryos
}

Tzu-Chun Tsai ${ }^{1,2}$, Jen-Kann Lư ${ }^{3}$, Sie-Lin Choo ${ }^{3}$, Shu-Yu Yeh ${ }^{3}$, Ren-Bing Tang ${ }^{2,4}$, Hsin-Yu Lee ${ }^{5}$ and Jen-Her Lü ${ }^{2,4^{*}}$

\begin{abstract}
Background: Dysmorphogenesis and multiple organ defects are well known in zebrafish (Danio rerio) embryos with T-box transcription factor 5 (tbx5) deficiencies, mimicking human Holt-Oram syndrome.

Methods: Using an oligonucleotide-based microarray analysis to study the expression of special genes in tbx5 morphants, we demonstrated that $\mathrm{GH}$ and some $\mathrm{GH}$-related genes were markedly downregulated. Zebrafish embryos microinjected with tbx5-morpholino $(\mathrm{MO})$ antisense RNA and mismatched antisense RNA in the 1-cell stage served as controls, while zebrafish embryos co-injected with exogenous growth hormone $(\mathrm{GH})$ concomitant with tbx5-MO comprised the treatment group.

Results: The attenuating effects of $\mathrm{GH}$ in tbx5-MO knockdown embryos were quantified and observed at 24, 30, 48, 72 , and $96 \mathrm{~h}$ post-fertilization. Though the understanding of mechanisms involving GH in the tbx5 functioning complex is limited, exogenous GH supplied to tbx5 knockdown zebrafish embryos is able to enhance the expression of downstream mediators in the GH and insulin-like growth factor (IGF)-1 pathway, including igfl, ghra, and ghrb, and signal transductors (erk1, akt2), and eventually to correct dysmorphogenesis in various organs including the heart and pectoral fins. Supplementary GH also reduced apoptosis as determined by a TUNEL assay and decreased the expression of apoptosis-related genes and proteins (bcl2 and bad) according to semiquantitative reverse-transcription polymerase chain reaction and immunohistochemical analysis, respectively, as well as improving cell cycle-related genes (p27 and cdk2) and cardiomyogenetic genes ( $a m h c, v m h c$, and cm/c2).

Conclusions: Based on our results, tbx5 knockdown causes a pseudo $\mathrm{GH}$ deficiency in zebrafish during early embryonic stages, and supplementation of exogenous $\mathrm{GH}$ can partially restore dysmorphogenesis, apoptosis, cell growth inhibition, and abnormal cardiomyogenesis in tbx5 knockdown zebrafish in a paracrine manner.
\end{abstract}

Keywords: tbx5, Growth hormone, Apoptosis, Embryogenesis, Zebrafish

\section{Background}

T-box transcription factor 5 (TBX5) is essential for cardiogenesis and forelimb development during embryogenesis in vertebrates. Mutation or haploinsufficiency of tbx5 in humans is related to Holt-Oram syndrome (HOS), which features congenital heart defects and forelimb deformities [1,2]. The TBX5 protein was proven to

\footnotetext{
* Correspondence: jklu@gmail.com

${ }^{2}$ School of Medicine, National Yang Ming University, Taipei, Taiwan, Republic of China

${ }^{4}$ Department of Pediatrics, Taipei Veterans General Hospital, Taipei, Taiwan, Republic of China

Full list of author information is available at the end of the article
}

be involved in determining early cell fate decisions, controlling differentiation and organogenesis, and regulating cardiac diastolic function in HOS patients [3,4]. In zebrafish, tbx5 deficiency provokes cascading effects on multiple transcriptional expressions and causes extensive developmental retardation [5,6]. In developing zebrafish (Danio rerio) embryos, the $t b \times 5$ gene is involved in the directed migration of individual lateral-plate mesodermal cells into future fin bud- and heart-producing regions [7], so embryos with the $t b x 5$ deficiency show anomalies in heart and pectoral fins that are identical to those in humans [6]. The $t b \times 5$ deficiency also diminishes the expressions of amhc/mhy6, vmhc, and $c m l c 2$, causes

\section{Biomed Central}


heart defects, and is associated with pectoral fin anomalies and developmental delays [8,9]. Furthermore, TBX5 regulates organogenesis by modifying the activities of many transcription factors [8,10-12].

Tbx5 also has essential roles in regulating progression of the cell cycle [13], cell growth, and apoptosis [14]. Blocking cell-cycle progression by tbx5 depletion at the RNA level leads to a decrease in the cardiac cell number, an alteration in the timing of the cardiac differentiation program, defects in cardiac sarcomere formation, and ultimately cardiac programmed cell death $[13,15]$.

$\mathrm{GH}$ belongs to the $\mathrm{GH} /$ prolactin (PRL) superfamily and functions by binding to homodimeric $\mathrm{GH}$ receptors. It is the major regulator of growth and is an important metabolic hormone [16]. Recent studies established that the GH/PRL superfamily is essential for organogenesis, such as that of the head, eyes, melanophores, and gas bladder in zebrafish [4]. Besides being implicated in growth, GH regulates gonad development, osmoregulation, and immunity in fish as well [17]. In GHtransgenic zebrafish, the overexpression of $\mathrm{GH}$ reduced the transcription of the antioxidant defense system and myogenesis-related genes [18], although the consequences of a shortage of $\mathrm{GH}$ in zebrafish embryos remain unknown.

Because the gain and loss of functions of $\mathrm{GH}$ in embryos cause developmental defects, $\mathrm{GH}$ is thought to play a vital role in embryogenesis. $\mathrm{GH}$ participates in embryonic development as a growth and differentiation factor, and in cell proliferation as an antiapoptotic factor and in meiotic progression [19,20]. Instead of pituitary $\mathrm{GH}$, maternal or local $\mathrm{GH}$ takes part in regulating early embryogenesis via paracrine/autocrine effects, since GH and its receptors exist prior to the formation of functional pituitary somatotrophs [21,22].

Even though there is no evidence to date that shows any interaction between TBX5 and GH, both of them work with allied functions in regulating apoptosis, the cell cycle, and myogenesis during embryogenesis. Therefore, the role of $\mathrm{GH}$ during embryogenesis in embryos with congenital defects caused by an insufficiency of TBX5 remains undetermined but significant. In our study, GH was microinjected into zebrafish embryos at the $1 \sim 4$-cell stages to reveal paracrine restoration effects from exogenous $\mathrm{GH}$ in $t b \times 5$ morphants.

\section{Methods}

\section{Animal ethics statement}

Approval of this experiment was permitted by the Animal Ethics Review Board of National Taiwan Ocean University Aquaculture. Since zebrafish embryo under 7 day (168 hour post-fertilization) is excluded in the definition of "vertebrate animal" in review board, our study which used zebrafish embryo under $48 \mathrm{hpf}$ was spared of regulation and review process of Basic Institutional Review Board (IRB).

\section{Maintenance of zebrafish}

Zebrafish were maintained in $45-\mathrm{L}$ aquaria heated to $28.5{ }^{\circ} \mathrm{C}$ with 25 fish per tank. The water was filtered, and about half of the water was replaced at least once a week. Adult zebrafish were fed 1 or 2 times per day with a variety of food, and the tank was cleaned by siphoning off any excess food after the second daily feeding. The day-night cycle was controlled with an automatic timer (14 h of light/10 h of dark).

\section{Breeding of zebrafish}

Zebrafish reach sexual maturity in $10 \sim 12$ weeks, but breeding fish should be $7 \sim 18$ months of age for maximum embryo production. The day before breeding, $1 / 3$ of the water was replaced and the tank was cleaned after feeding ( $1 \sim 2 \mathrm{~h}$ before the end of the light period). Finally, a collection box was placed at the bottom of the tank, and preparations were made to collect the embryos the next day.

\section{Embryo collection}

We removed the collection box in the morning when the light was turned on and placed the collected embryos into an incubator maintained at a temperature of $28.5^{\circ} \mathrm{C}$.

\section{RNA isolation}

Total RNA was isolated from 50 embryos using the guanidine isothiocyanate-based TRIzol solution. RNA samples were re-suspended in DEPC-treated water and quantified spectrophotometrically at $260 \mathrm{~nm}$. The RNA quality was then checked by $1.2 \%$ agarose gel electrophoresis, after staining with $1 \mu \mathrm{g} / \mathrm{ml}$ ethidium bromide. The RNA stock solution was stored at $-80{ }^{\circ} \mathrm{C}$.

\section{Microarray}

Isolated total zebrafish embryo RNA was purified using an RNeasy ${ }^{\circledR}$ Mini Kit (QIAGEN, Hilden, Germany), and the quality was confirmed using an Aglient 2100 Bioanalyzer (Aglient Technologies, Santa Cruz, CA, USA). Purified RNA was reverse-transcribed into complementary (c)DNA using SuperScrip TM III RT (Invitrogen, Carlsbad, CA, USA). Before purifying and coupling the fluorescent dye using indirect cDNA labeling with a microarray kit (Invitrogen), the cDNA was hydrolyzed and neutralized using $\mathrm{NaOH}$ and $\mathrm{HCl}$. The cDNA was then pretreated with GEx hybridization buffer (HI-PRM; Aglient Technologies) before transferring to hybridization chamber gasket slides for the hybridization reaction. The slide was scanned with an Axon Instruments GenePix 4000B scanner (Molecular Devices, Silicon Valley, CA, 
USA) and data analyzed with Genespring GX 10.0.2 (Aglient Technologies). All data is MIAME compliant and the raw data has been deposited in a GEO database (GSE33965) [NCBI tracking system \#16217606].

\section{Semiquantitative reverse-transcriptase polymerase chain reaction (RT-PCR)}

Total RNA was prepared from 50 defective or normal embryos (Invitrogen), with amplification of $3 \mu \mathrm{l}$ of 1ststrand cDNA. Amplification primers for each specific mRNA deduced from published sequences were igf1 (P1: 5'-TCTCATCCTCTTTCTCGC-3', P2: 5'-GATAGTTTCTGCCCCC-3'), ghra (P1: 5'-AAGCATTGAGAGGTG3', P2: 5'-AGAGGAAGTGAGGAGAA-3'), ghrb (P1: 5'GTTCCACCCGTTTTCA-3', P2: 5'-GCGAGTCCTCATTCTGT-3'), akt2 (P1: 5'-GAAGAGGATGAGCCAATG3' and P2: 5'-CTCCAACGCTGAAACAAT-3'), and erk1 (P1: 5'-TCTGCCAATGTGCTGC-3', P2: 5'-TGCCGTCTCCTCAAAG-3'). PCR conditions were comprised of denaturation at $95{ }^{\circ} \mathrm{C}$ for $3 \mathrm{~min}$ followed by 50 cycles of amplification $\left(95{ }^{\circ} \mathrm{C}\right.$ for $20 \mathrm{~s}, 59{ }^{\circ} \mathrm{C}$ for $15 \mathrm{~s}$, and $72{ }^{\circ} \mathrm{C}$ for $20 \mathrm{~s}$ ).

\section{Microinjection and morpholino (MO) treatment}

The MO antisense oligonucleotide, tbx5-MO (5-GAAAGGTGTCTTCACTGTCCGCCAT-3), was designed against the $t b x 5$ translational start site (Gene Tools, Philomath, OR, USA). Wild-type (WT) embryos, primarily at the 1-cell stage with the chorion intact, were injected with $19.4 \mathrm{ng} / 4.3 \mathrm{nl}$ of stock MO diluted in Danieau's solution. Injected embryos were raised at $28.5^{\circ} \mathrm{C}$. Embryos used for analyzing the expression of various markers were fixed with $4 \%$ paraformaldehyde. Otherwise, embryos were scored after 2 days of development for late effects. In our previous study, 4 control groups, including the $3^{\prime}$ end of $t b x 5-\mathrm{MO}(2)$ (5'-GCCTGTACGATGTCTACCGTGAGGC-3'), mismatched tbx5-MO (5'-GTCTCTTGACTCTCCGCGATCTCGG-3'), and embryos with blank microinjection and wild-types without microinjection, were included to identify the specific blockage of $t b \times 5$ mRNA translation effect of $t b \times 5-\mathrm{MO}$ [9]. The efficacy and specificity of the $t b x 5-\mathrm{MO}$ has been confirmed in previous published articles $[9,14]$.

\section{Exogenous treatment with $\mathrm{GH}$}

Zebrafish embryos were micro-injected with $1 \mathrm{fM}$ of human GH (Sigma-Aldrich, St. Louis, MO, USA) ( $n=150$ /group, with triplicate determinations), accompanied by $19.4 \mathrm{ng} / 2.3 \mathrm{nl} t b x 5-\mathrm{MO}$ at the 1-cell stage. Treated zebrafish embryos were placed into plates with wells, and their functional classification was evaluated at 30, 48, 72, and $96 \mathrm{~h}$ post-fertilization (hpf).

\section{Normal morphological growth rate assessment}

Treated zebrafish embryos were placed into a plate with wells for longitudinal follow-up at $12 \sim 18$-h intervals. The normal morphological growth rate was evaluated at 24, 30, and $48 \mathrm{hpf}$.

\section{Whole-mount in situ hybridization}

Whole-mount in situ hybridization was performed as previously described by Schulte-Merker et al. [23]. The digoxigenin-labeled antisense full-length $a m h c, v m h c$, and $c m l c 2$ RNA probes were transcribed using T7 RNA polymerase (Promega, Madison, WI, USA). Wholemount in situ hybridization was carried out essentially as described by Oxtoby and Jowett [24]. In brief, embryos were fixed with $4 \%$ paraformaldehyde, digested with proteinase $\mathrm{K}$, and hybridized with the zebrafish $a m h c$, vmhc, or $c m l c 2$ probes at $67{ }^{\circ} \mathrm{C}$. An alkaline phosphataseconjugated anti-digoxigenin antibody (Boehringer Mannheim, Dassel, Germany) was used to detect zebrafish amhc, vmhc, or $c m l c 2$ signals. After staining with NBT/ BCIP (Boehringer Mannheim), embryos were re-fixed with $4 \%$ paraformaldehyde and stored in phosphatebuffered saline (PBS).

\section{Immunohistochemical analysis}

Zebrafish embryos were fixed with $4 \%$ paraformaldehyde in PBS. De-paraffinized sections $(3 \mu \mathrm{m})$ of zebrafish embryo tissues were placed on slides and processed for immunohistochemistry. After application of a biotin blocking system (Dako, Glostrup, Denmark) for $30 \mathrm{~min}$, sections were incubated with target-purified rabbit primary antibodies, including $\mathrm{Bcl} 2, \mathrm{Bad}, \mathrm{Cdk} 2$, and P27 (all from Anaspec, Fremont, CA, USA) washed in PBS, and then incubated with a rhodamine-conjugated secondary antibody, goat anti-rabbit immunoglobulin G (IgG). After washing in PBS, sections were incubated with mounting medium and kept at $4{ }^{\circ} \mathrm{C}$.

\section{Transmission electron microscopic (TEM) examinations}

Embryos were fixed at $48 \mathrm{hpf}$ with $2.5 \%$ glutaraldehyde in Sorenson's phosphate buffer, post-fixed with $1 \%$ $\mathrm{OsO}_{4}$ in Sorenson's phosphate buffer followed by dehydration through a graded series of ethanol washes, and embedded in Spurr's EPON. Blocks were heated in an oven for $8 \mathrm{~h}$ at $70{ }^{\circ} \mathrm{C}$. Semi-thin $(1 \mu \mathrm{m})$ sections were cut and stained with toluidine blue for adequate preview under a microscope. Ultrathin sections (900 $⿱$ ) were cut with a diamond knife, stained with uranyl acetate and lead citrate, and examined with an electron microscope.

\section{TdT-UTP nick end labeling (TUNEL) assay}

Both whole mount and sectioned TUNEL assays were performed using an ApopTag kit (Chemicon, Heule, Belgium). Zebrafish embryos were briefly fixed with $4 \%$ 
paraformaldehyde in PBS. Proteinase K-treated whole embryos or de-paraffinized sections $(5 \mu \mathrm{m})$ of embryos were incubated with the TdT enzyme followed by antidigoxigenin. Finally, embryos or slides were stained with $\mathrm{DAB}$ for $5 \mathrm{~min}$.

\section{Western blot analysis}

Embryos were homogenized on ice in lysis buffer (SigmaAldrich). Cellular debris was then pelletized by centrifugation at 12,000 rpm for $20 \mathrm{~min}$, and the supernatant was collected and measured. Proteins were mixed with sample buffer before separation in $10 \%$ sodium dodecylsulfate polyacrylamide electrophoresis (SDS-PAGE) gels. The SDS-PAGE was then transferred onto nitrocellulose membranes at $100 \mathrm{~V}$ for $1 \mathrm{~h}$. Membranes were blocked with $5 \%$ bovine serum albumin (BSA) buffer at room temperature for $1 \mathrm{~h}$. The Akt and Erk primary antibody (Aviva Systems Biology, San Diego, CA, USA) was incubated overnight at $4{ }^{\circ} \mathrm{C}$ at a dilution of $1: 1000$. Nitrocellulose membranes were washed with PBST followed by incubation with a horseradish peroxidase (HRP)-conjugated secondary antibody (1:5000) for $1 \mathrm{~h}$ at room temperature before the images were digitized.

\section{Statistical analysis}

Results are given as the mean \pm S.D. Where applicable, Duncan's new multiple range test was used to compare every pair of testing groups. Statistical significance was accepted at $p<0.05$.

\section{Results}

The $t b \times 5$ insufficiency causes morphological changes during zebrafish embryonic development

At $48 \mathrm{hpf}$, looped hearts with apparent chambers (atria and ventricle) were observed in WT zebrafish embryos (Figure 1A), their trunks appeared straight without bending, and somites were "V-shaped" (Figure 1F). At $96 \mathrm{hpf}$, they displayed well-formed pairs of pectoral fins (Figure. 1K). Perturbations of cardiac development (Figure $1 \mathrm{~B}$ ) were exhibited in tbx5-MO treated (MO) zebrafish embryos, along with curved trunks and abnormal "U-shaped" somites (Figure 1G), and pectoral fin growth (Figure 1L) was either truncated or even atretic. Moreover, the defect rates in the heart (Figure 1P), trunk (Fig. 1Q), and pectoral fins (Figure 1R) were very high in the MO group compared to those of the WT and mismatch tbx5-MO-treated (MIS) groups. Formation of the heart (Figure 1C), trunk (Figure $1 \mathrm{H}$ ), and pectoral fins (Figure $1 \mathrm{M}$ ) in the MIS and WT groups was similar.

\section{Multiple growth-related genes were downregulated in tbx5 knockdown embryos}

We screened growth-related genes that were downregulated after knockdown of $t b x 5$ using a zebrafish microarray.
Genes that were $1.5 \times$ downregulated were included. Multiple genes participating in growth were downregulated in zebrafish embryos with the $t b x 5$ deficiency (Table 1 ). Growth-related genes igfbp $2 b$, ghra, ing4, $m d k b$, grb2, veg$f a a$, and fibpl were downregulated at the heart-tube stage at $24 \mathrm{hpf}$. At $30 \mathrm{hpf}$, when the heart begins to loop, pdgfab, $g h 1, f g f 1, f g f 6 a$, and vegfab were downregulated in $t b x 5$ knockdown embryos. Furthermore, gata5 and ghrl were found to be downregulated at $48 \mathrm{hpf}$.

\section{Exogenous GH-improved embryonic defects in zebrafish with tbx5 deficiency}

Data from microarray screening showed that $\mathrm{GH}$ was downregulated in the early embryonic stages in zebrafish embryos with the $t b x 5$ deficiency. WT embryos did not show defects of the heart (Figure 1P), pectoral fins (Figure 1Q), or trunk (Figure 1R). Microinjection of GH into tbx5-MO treated embryos (MOGH group) caused defects of the heart $(22.7 \%$ at $24 \mathrm{hpf}, 37.3 \%$ at $30 \mathrm{hpf}$, and $46.7 \%$ at $48 \mathrm{hpf}$; Figure $1 \mathrm{P})$, pectoral fins $(61.3 \%$ at $24 \mathrm{hpf}, 64.7 \%$ at $30 \mathrm{hpf}$, and $65.3 \%$ at $48 \mathrm{hpf}$; Figure 1Q), and trunk (45.3\% at $24 \mathrm{hpf}, 45.3 \%$ at 30 hpf, and $46.7 \%$ at 48 hpf; Figure 1R).

Microinjection of $t b x 5-\mathrm{MO}$ into WT embryos (the MO group) caused specific defects of the heart (stringlike heart, cardiac edema, and loss of ventricular contractility) (51.3\% at $24 \mathrm{hpf}, 74.7 \%$ at $30 \mathrm{hpf}$, and $96 \%$ at $48 \mathrm{hpf}$; Figure $1 \mathrm{P})$, pectoral fins ( $85.3 \%$ at $24 \mathrm{hpf}, 88 \%$ at $30 \mathrm{hpf}$, and $88 \%$ at $48 \mathrm{hpf}$; Figure 1Q), and trunk (76\% at $24 \mathrm{hpf}, 80 \%$ at $30 \mathrm{hpf}$, and $78.7 \%$ at $48 \mathrm{hpf}$; Figure 1R). Comparing the MO group to the MOGH group, the incidence of embryonic defects due to $t b \times 5$ insufficiency was significantly reduced (Figure 1P-R).

Compared to the WT group, microinjection of exogeneous GH into WT embryos (WTGH) did not cause significant phenotypic changes, and no embryonic defects were identified (Figure 1P-R). There were no statistical differences in embryonic defects between the WT group $(n=50)$ and either the MIS group $(n=50)$ or the WTGH group $(n=50)$.

\section{The paracrinous effect of exogenous GH in activating the IGF-1 pathway}

Genes participating in the GH/IGF-1 pathways, igf1 (Figure 2A), ghra (Figure 2B), and ghrb (Figure 2C), were downregulated in the MO group but were partly reactivated in the study groups simultaneously treated with $\mathrm{GH}$ (Figure 2A-C). On the other hand, genes participating in the GH/IGF-1 pathway showed no statistically significant differences in the WT group and MIS group (Figure 2A, B, C).

Since the affected receptors function through phosphorylation, we examined the expression of phosphorylationrelated genes, erk1 and $a k t 2$, at the protein and gene levels 


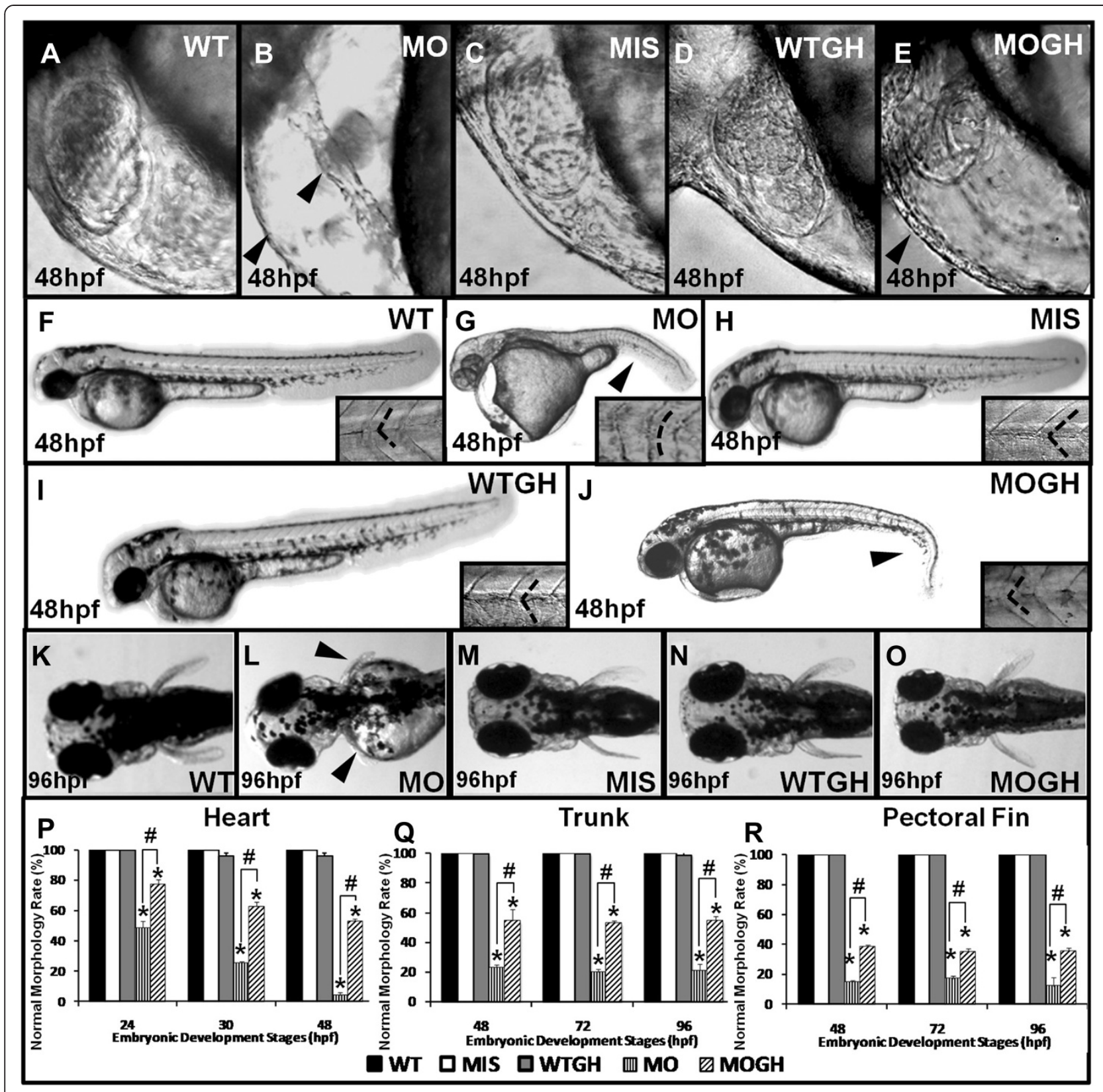

Figure 1 Phenotypes of $t b x 5$ knockdown and GH-treated zebrafish embryos. The normal appearance of hearts in wild-type (WT) (A) and MIS (C) group embryos and string-like hearts occurring in MO (B) group embryos are depicted. In WTGH embryos (D), hearts are identical to those of the WT (A) group, and hearts of MOGH group embryos (E) showed improvements. No significant differences were observed in trunks of WT $(\mathbf{F})$, MIS $(\mathbf{H})$, and WTGH group embryos (I), in which trunks were straight and somites appeared "V-shaped." On the other hand, trunks of embryos injected with tbx5-MO were severely bent $(\mathbf{G})$ and had "U-shaped" somites, but these were partially restored in MOGH group embryos (J). In the MO group (L), truncated or undeveloped pectoral fins were demonstrated; nevertheless, WT (K) embryos micro-injected with mismatched tbx5-MO (M), WT (N) exogenous GH-treated embryos, and tbx5-deficient embryos exhibited normal appearances. Statistically, the normal morphogenetic rates of the heart $(\mathbf{P})$, trunk $(\mathbf{Q})$, and pectoral fins $(\mathbf{R})$ were significantly lower in the $\mathrm{MO}$ group and partially improved in the MOGH group. Defective embryos were not found in the WT or MIS groups and almost all of the embryos in the WTGH group developed properly. Data are presented as mean \pm S.D. ${ }^{*} p<0.05$ vs. WT; ${ }^{\#} p<0.05 \mathrm{MO}+\mathrm{GH}$ vs. MO. Black arrowhead, defect site; dashed line, shape of somite border; MO, tbx5 knockdown; MIS, mismatch tbx5-MO-treated embryos; WTGH, WT embryos treated with GH; MOGH, tbx5-MO- and GH-treated embryos. 
Table 1 1.5x down regulated growth -related genes in tbx5 knockdown embryos in different embryonic developmental stages

\begin{tabular}{|c|c|c|c|c|c|}
\hline $\begin{array}{l}\text { Gene } \\
\text { Symbol }\end{array}$ & Gene Name & Genbank \# & Function & $\begin{array}{l}\text { Stage } \\
\text { (hpf) }\end{array}$ & Reference \\
\hline igfbp $2 b$ & $\begin{array}{l}\text { insulin-like growth factor } \\
\text { protein } 2 b\end{array}$ & NM_131458 & $\begin{array}{l}\text { general embryonic development and } \\
\text { growth, regulating vascular development }\end{array}$ & 24 & Zhou, 2008 \\
\hline ghra & growth hormone receptor a & NM_001083578 & cytokine receptor activity & 24 & $\begin{array}{l}\text { Di Prinzio, } \\
2010\end{array}$ \\
\hline ing4 & $\begin{array}{l}\text { inhibitor of growth family, } \\
\text { member } 4\end{array}$ & NM_001020468 & $\begin{array}{l}\text { regulating brain tumour growth and } \\
\text { angiogenesis }\end{array}$ & 24 & $\begin{array}{l}\text { Susan Nozell, } \\
2008\end{array}$ \\
\hline$m d k b$ & midkine-related growth factor $\mathrm{b}$ & NM_131716 & $\begin{array}{l}\text { brain development, neural crest } \\
\text { formation }\end{array}$ & 24 & Liedtke, 2008 \\
\hline grb2 & $\begin{array}{l}\text { growth factor receptor-bound } \\
\text { protein } 2\end{array}$ & NM_213035 & $\begin{array}{l}\text { distinct effects on neural crest and } \\
\text { floorplate development }\end{array}$ & 24 & $\begin{array}{l}\text { Ryan P } \\
\text { Million, } 2004\end{array}$ \\
\hline vegfaa & $\begin{array}{l}\text { vascular endothelial growth } \\
\text { factor } \mathrm{Aa}\end{array}$ & AF016244 & $\begin{array}{l}\text { blood vessel endothelial cell } \\
\text { proliferation }\end{array}$ & 24 & Bahary, 2007 \\
\hline fibpl & $\begin{array}{l}\text { fibroblast growth factor (acidic) } \\
\text { intracellular binding protein, like }\end{array}$ & NM_212861 & Kupffer's vesicle development & 24 & Hong, 2009 \\
\hline pdgfab & $\begin{array}{l}\text { platelet derived growth } \\
\text { factor alpha b }\end{array}$ & NM_001076757 & positive regulation of cell division & 30 & $\begin{array}{l}\text { Eberhart, } \\
2008\end{array}$ \\
\hline gh1 & growth hormone 1 & NM_001020492 & growth control & 30 & Toro, 2009 \\
\hline$\overline{f g f 1}$ & fibroblast growth factor 1 & NM_200760 & hemopoiesis & 30 & $\begin{array}{l}\text { Songhet, } \\
2007\end{array}$ \\
\hline vegfab & $\begin{array}{l}\text { vascular endothelial growth } \\
\text { factor } A b\end{array}$ & NM_001044855 & angiogenesis & 30 & Bahary, 2007 \\
\hline gata5 & GATA-binding protein 5 & NM_131235 & specification of cardiomyocytes & 48 & $\begin{array}{l}\text { Holtzinger, } \\
2007\end{array}$ \\
\hline$\overline{g h r l}$ & ghrelin/obestatin preprohormone & NM_001083872.1 & encodes ghrelin-obestatin preproprotein & 48 & Li, 2009 \\
\hline
\end{tabular}

using Western blot and semiquantitative RT-PCR, respectively. Gene expression levels of erk1 (Figure 2E) and akt2 (Figure 2F) could be identified at 24, 30, and $48 \mathrm{hpf}$, but were depressed in embryos with the $t b \times 5$ deficiency. Exogenous GH increased the expression of genes and proteins in embryos with the $t b x 5$ deficiency, but these expressions caused no significant changes in the MIS group (Figure 2E, F). GH downstream factors Erk and Akt, however, were significantly reduced in the MO group, and their gene expressions were improved in the MOGH group.

Expressions of the phosphorylation-related genes of erk1 and akt2 in the WT, MIS, and WTGH microinjection groups were similar (Figure 2D-F).

\section{Exogenous GH partially normalized the apoptotic effect induced by $t b \times 5$ deficiency}

The TUNEL assay demonstrated only few apoptotic spots in WT (Figure 3A), MIS (Figure 3B), and WTGH embryos (Figure $3 \mathrm{C}$ ). Apoptotic spots were significantly induced in the MO group (Figure 3D) and were diminished in the MOGH-treated group (Figure 3E).

We analyzed the expressions of cell apoptosis-related genes at the RNA and protein levels. Our results showed a remarkable increase of bcl2 (Figure 4A) and bad
(Figure 4B) in $\mathrm{MO}$ group embryos in all studied periods. However, compared to gene expression in the WT group, no significant changes were found in embryos injected with either MIS or WTGH (Figure 5A, B). Overexpression of the bad and $b c l 2$ genes was then confirmed by analyzing their protein expressions by performing immunohistochemical analyses in the heart and pectoral fins at 30 hpf. Bad and Bcl2 genes showed identical protein expression patterns, which were observed in messenger $(\mathrm{m})$ RNA expression analysis in the heart and pectoral fins (Figure 4C-R). Mild expressions of the apoptosis-related proteins, Bad and $\mathrm{Bcl} 2$, were observed in the heart (Figure 4C, G) and pectoral fins (Figure 4K, 4O) of WT embryos, and increased expressions of $\mathrm{Bad}$ and $\mathrm{Bcl} 2$ were detected in the heart (Figure 4E, I) and pectoral fins (Figure 4M, Q) of tbx5 knockdown embryos. Expression levels of apoptosis-related proteins were observed in the heart (Figure 4D, F, H, J) and pectoral fins (Figure. 4L, N, P, R) of the WTGH and MOGH groups.

Effect of exogenous $\mathrm{GH}$ on genes related to the cell cycle Depletion of $t b \times 5$ caused an increase in the expressions of S stage-related mRNA $p 27$ and $c d k 2$ (Figure 5A, B) in tbx5 morphants. However, in the MOGH group, expressions of $p 27$ and $c d k 2$ were partially restored, which 
A

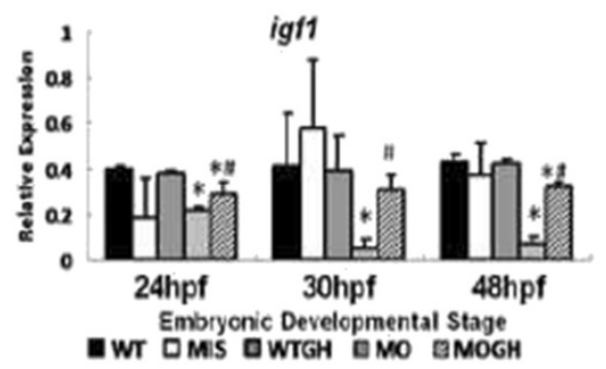

B

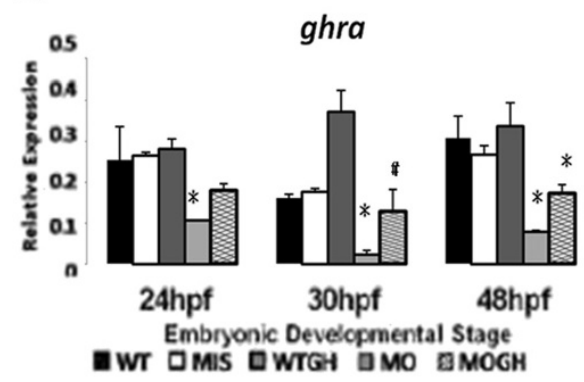

C

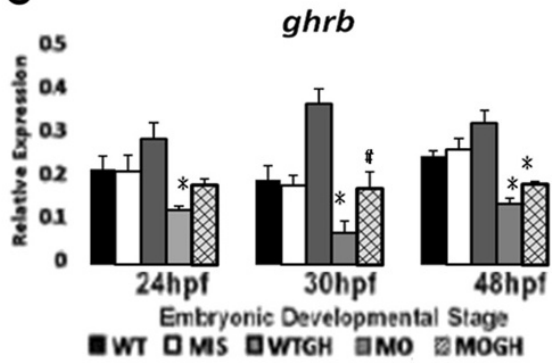

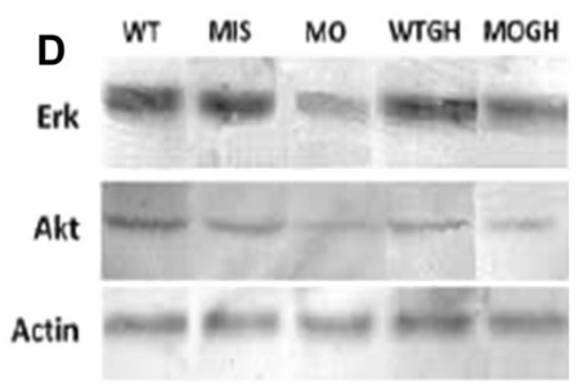

E

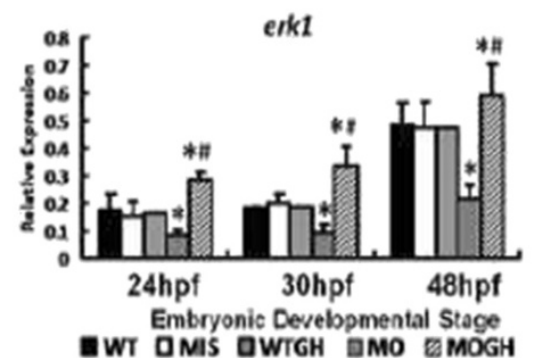

$\mathbf{F}$

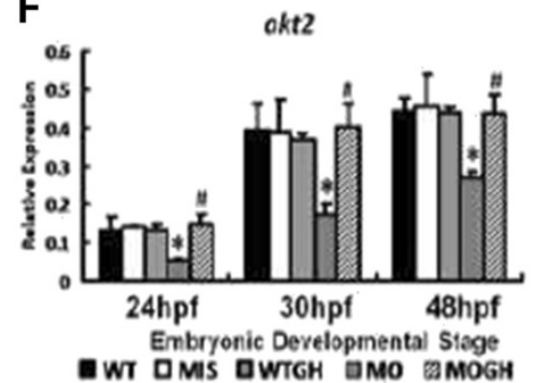

(Relative expression= gene expression / Bactin expression)

Figure 2 Expressions of igf1, ghra, ghrb, akt2, and erk1 in tbx5 knockdown embryos. (A) The expression of igf1 was significantly reduced in MO group embryos throughout the developmental stages. Its expression in WTGH and MIS embryos was similar to the control and wild-type (WT) groups. The expression of igfl was significantly restored in the WTGH treatment group. Expressions of GH receptors ghra (B) and ghrb (C) were significantly depressed in MO embryos but restored in the MOGH treatment group. (D) In the Western blot analysis, protein expressions of Akt and Erk in MO zebrafish embryos were depressed, but expressions were similar among the WT, MIS, and WTGH groups at $30 \mathrm{~h}$ postfertilization (hpf). Expressions of Akt and Erk were restored in the MOGH group. In the semiquantitative PCR analysis, mRNA expressions of erk1 (E) and akt2 (F) were significantly reduced in MO group embryos and restored in the MOGH group. Data are presented as the mean \pm S.D. ${ }^{*} p<0.05$ vs. WT; \# $p<0.05$ MOGH vs. MO. MO, tbx5 knockdown; MIS, mismatched tbx5-MO-treated embryos; WTGH, WT embryos treated with growth hormone (GH); MOGH, tbx5-MO- and GH-treated embryos.

showed no significant difference compared to the WT or MIS groups (Figure 5A, B).

mRNA expressions of cell cycle-related genes were confirmed by performing an immunohistochemical analysis. Protein expressions of Cdk2 and P27 in the heart and pectoral fins had similar patterns as observed in the mRNA expression analysis (Figure 5C-R). Expressions of cell cycle-related proteins, Cdk2 and P27, were observed in the heart (Figure. 5C, G) and pectoral fins (Figure 5K, O) of WT embryos. Expressions of Cdk2 and P27 were induced in the heart (Figure. 5E, I) and pectoral fins (Figure 5M, Q) of MO-group embryos. Protein expression levels of Cdk2 and P27 were identical in the heart (Figure 5D, 5 F, 5 H, 5J) and pectoral fins (Figure 5L, N, $\mathrm{P}, \mathrm{R})$ of the WTGH and MOGH groups.

\section{Exogenous GH improves the expression of} cardiomyogenesis genes in $t b \times 5$ knockdown embryos The result of whole-mount in situ hybridization demonstrated that the expressions of amhc, vmhc, and $c m l c 2$ 

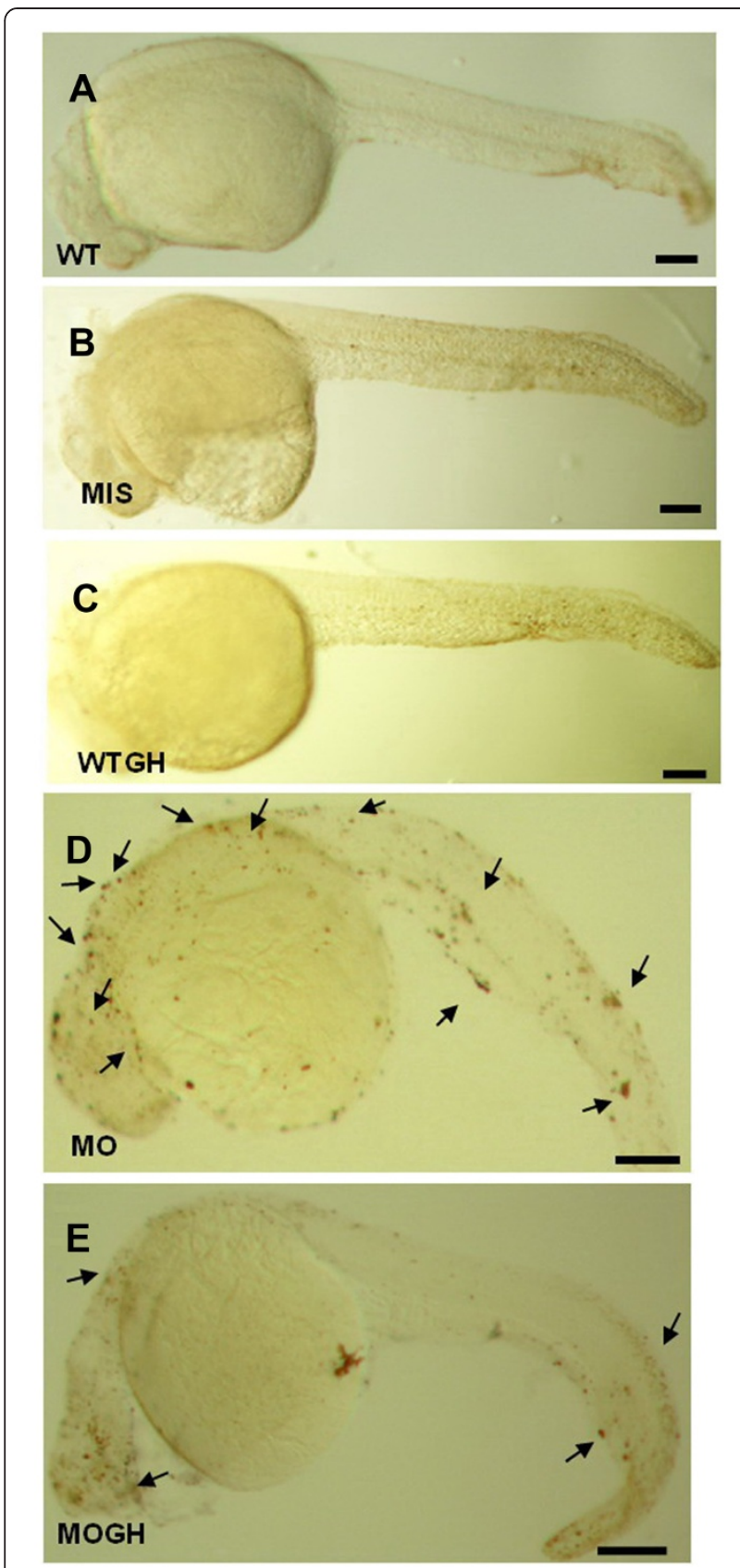

Figure 3 Growth hormone (GH)-treated tbx5-knockdown zebrafish embryos show reduced apoptosis at $30 \mathrm{~h}$ post-fertilization (hpf). A TUNEL assay revealed no apoptotic spots in WT (A), MIS (B), and WTGH (C) embryos. (D) However, massive apoptotic spots were visible in $\mathrm{MO}$ embryos. (E) In the MOGH group, apoptotic sites were reduced. (A-E) Embryo anteriors are to the left. Scale bar $=0.1 \mathrm{~cm}$. Black arrow, apoptotic site; WT, wild-type embryos; MO, tbx5 knockdown; MIS, mismatched tbx5-MO-treated embryos; WTGH, WT embryos treated with GH; MOGH, tbx5-MO- and GH-treated embryos.

were reduced in $t b x 5$ knockdown embryos (Figure 6G-I) compared to WT embryos (Figure 6D-F); however, in the MOGH group, expressions of amhc (Figure. 6J), $v m h c$ (Figure $6 \mathrm{~K}$ ), and $c m l c 2$ (Figure $6 \mathrm{~L}$ ) were improved. In a semiquantitative RT-PCR test, the expression of amhc was repressed at $48 \mathrm{hpf}$ in the MO group and was improved in the MOGH treatment group (Figure 6A). On the other hand, expressions of vmhc (Figure 6B) and cmlc2 (Figure 6C) were significantly repressed in all developmental stages in $t b x 5$ knockdown embryos but were significantly improved in the MOGH-treated group. Their expressions in the MIS, WTGH, and WT groups were similar (Figure 6A-C).

\section{Discussion}

Significant dysmorphogenesis (Figure 1) shown in the MO group is similar to congenital defects in humans with HOS. The defects of a string heart $[6,10,11,15,25$ 29] and dysgenetic fins [30-32] are well studied in several species models with $t b x 5$ insufficiency, especially zebrafish. We also explored those genes associated with altered $t b x 5$ levels during embryogenesis and those which contribute to developmental defects. We investigated gene expressions in dysmorphogenesis of a zebrafish $t b x 5$-deficient model in order to reveal the role of $t b x 5$ in altering transcription using an oligonucleotidebased microarray analysis, as it is sensitive to a single injection of $t b x 5$ morpholino in zebrafish embryos. Our microarray analysis results identified many genes with different functions and different categories that were up- or downregulated in zebrafish embryos with $t b x 5$ deficiency by morpholino in the early stages of organogenesis. Among these genes, some associated with growth, including igfpb2b, gh1, ghr1, and ghra, which occur respectively during different time windows of embryogenesis and are normally activated during different stages of early organogenesis, were appreciably depressed in embryos with $t b x 5$ deficiency [32-35]. A deficiency in $t b x 5$ leads to multiple organ defects including the heart, trunk, and pectoral fins, and also decreases the expressions of $g h 1(g h)$, and ghra [32,36]. Our data also revealed that knockdown of $t b \times 5$ in embryos diminished GH/IGF-1 pathway mediators, including GH, IGF-1, and GH receptors.

Exogenous GH was used in our study to partially restore the anomalies during embryogenesis to ensure the involvement of $\mathrm{GH}$ in multiple organ defects by tbx 5 knockdown. In the study, we injected human recombinant GH, which human GH instead of zebrafish GH is reported to have full activity in fish as well as in human [37], into the yolk of the zebrafish embryos as an alternative of soaking the embryos with $\mathrm{GH}$-contain water. Partially because the $\mathrm{GH}$ containing water solution is difficult to control the concentration, partially microinjection remains the most effective methods to introduce DNA, RNA, and proteins into fertilized zebrafish eggs and embryos [38]. Theoretically, the recombinant 


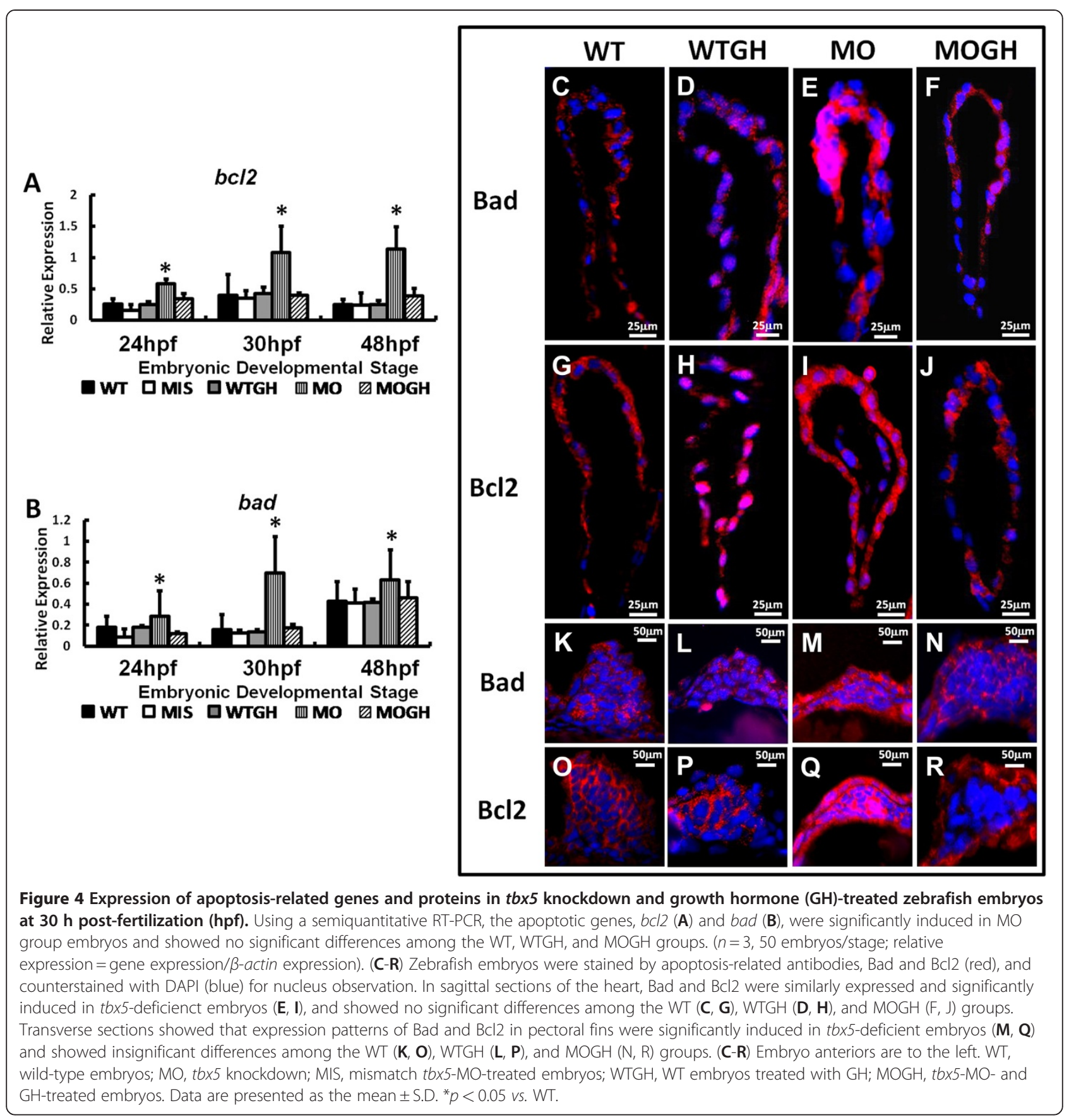

GH could be successfully delivered into the yolk of 1-2 cell stages and diffused into most embryonic cells of blastomere via intercellular substance. The expression of igf1, ghra, ghrb, erk1, and akt2 genes was increasing after co-injection with $\mathrm{GH}$ and tbx5 morpholino at 1-cell stage. These results revealed the exogenous $\mathrm{GH}$ has activated the downstream signaling pathway. However, it is still unknown how and where the exogenous $\mathrm{GH}$ binds with the $\mathrm{GH}$ receptors. Whether the injected exogenous human $\mathrm{GH}$ is packaged and sent outward to bind with the membranous $\mathrm{GH}$ receptors, or it directly binds with the cytoplasmic $\mathrm{GH}$ receptors, remains unidentified because the expression of $\mathrm{GH}$ receptors could be either in the nucleus or cytoplasm, or both, in different embryonic tissues and cells [39].

Exogenous $\mathrm{GH}$ in zebrafish embryos with $t b x 5$ deficiency could activate expression of $\mathrm{GH}$ receptor genes, to induce an increase in igf1 levels, and to elevate downstream Akt and Erk systems, coinciding with restoration of morphological anomalies and transcriptional cascades. 


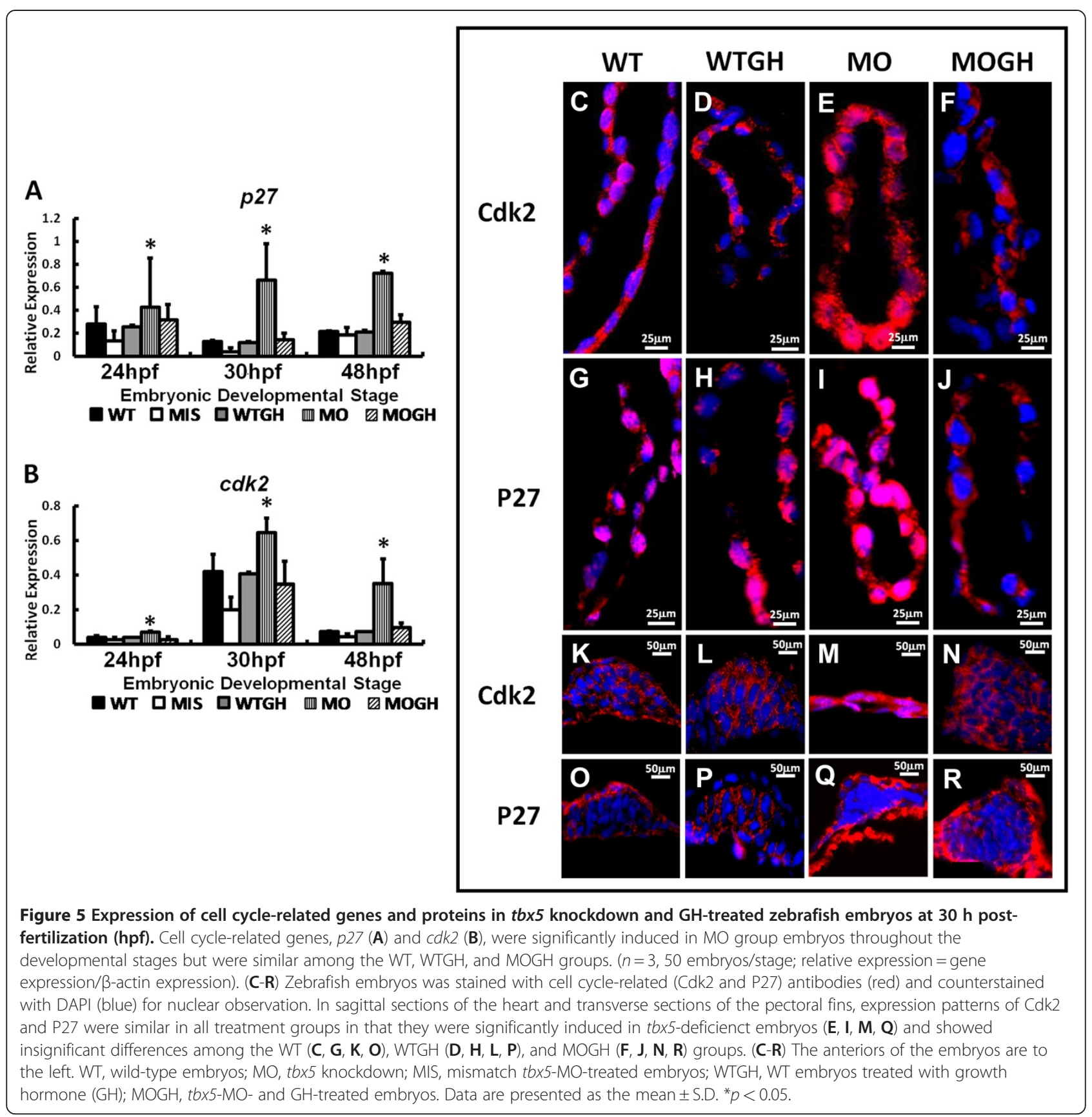

It could be hypothesized that $\mathrm{GH}$ is a factor that may act in a paracrine manner within the $t b \times 5$ functional pathway to modulate embryonic development.

$T b \times 5$ is essential for regulating the progression of the cell cycle by controlling the length of the embryonic cardiac cell cycle [13] and regulating apoptosis in endocardial cells, myocardial cells and the septum primum [40], all of which contribute to abnormal cardiogenesis. $\mathrm{GH}$ influences the growth of embryonic cells and modulates embryo cell cycle and proapoptotic metabolism [41]. In our study, exogenous GH partially restored the expression of $t b \times 5$ downregulated genes, which contributes to developmental delays in organogenesis including the cell cycle ( $p 27$ and $c d k 2)$ and apoptosis ( $b c l 2$ and $b a d)$. Early administration of exogenous $\mathrm{GH}$ improves the outcome of $t b \times 5$-deficiency-mediated heart defect embryos probably by inducing cardiac cells to re-enter the cell cycle. It also reduces aberrant apoptosis because GH works in a similar way to stimulate the cardiomyocyte to re-enter the cell cycle and thereby increases the number of 


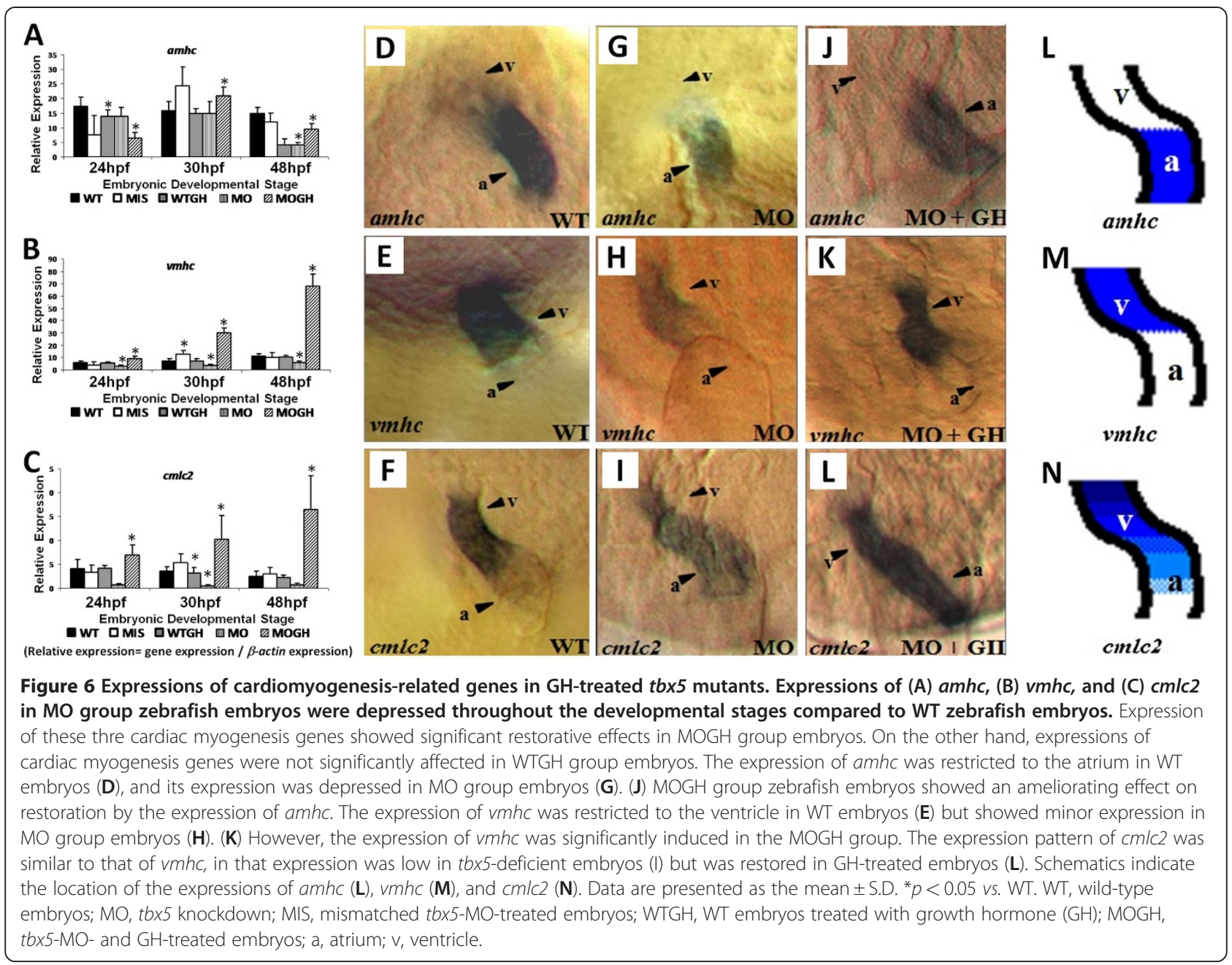

cardiac myocytes in ischemic and infarcted myocardia $[3,26]$.

The GH signaling pathway governs cell growth, proliferation, and apoptosis by controlling key regulatory genes that execute these processes. Herein, we also provide the first evidence that tbx 5 acts together with $\mathrm{GH}$ to regulate cardiac myogenetic pathway-responsive genes (cmlc2, amhc, and vmhc). Exogenous $\mathrm{GH}$ restored the expression levels of $a m h c, v m h c$, and $c m l c 2$ in our $t b x 5$ morphant embryos with cardiac defects. Inactivation of tb $\times 5$ diminished $a m h c, v m h c$, and $c m l c 2$ expressions, and although it also reduced heart size, exogenous $\mathrm{GH}$ reversed that result and enhanced cardiac formation in zebrafish embryos. Our results indicate not only that GH is necessary for the growth of these cardiac structures, but also that supplementary exogenous GH restores tbx 5 knockdown-mediated defects, including dysmorphogenesis and cardiomyogenesis, via cell proliferative and apoptotic pathways. It could be concluded that knockdown of tbx5 in early zebrafish embryogenesis causes functional GH deficiency and leads to dysmorphogenesis.
The comorbidity of morphologic defects and functional GH deficiency could be observed in early embryogenesis of $t b \times 5$ morphants and implied that GH may involve a role in embryogenesis including cardiomyogenesis through transcriptional regulation of $t b x 5$.

We found no literature underlining the interaction or the relationship between $t b x 5$ and growth-related genes shown in Table 1. This is especially true for GH. TBX5 is a member of the T-box transcription factor family. It has a sequence-specific DNA-binding site that improves an inducible recognition element of TBX5 that binds to a specific DNA sequence [42]. Thus, $t b x 5$ synergistically activates transcriptional regulation of downstream gene expression and controls the transcription of genetic information in embryonic development. In many $t b x 5$ mutants, affinities bound to a specific DNA target site were reduced by a variable amount, and even the ability to bind nonspecific DNA differs. Both contribute to the misregulation of target gene expression.

GH exerts different actions in different tissues through a complex functioning pathway involving many growth 
factors and their receptors [43]. It is mainly supposed to act through mediation of the GH/IGF-1 pathway, including $\mathrm{GH}$ receptors and cytoplasmic and intranuclear factors. Though the relationship between tbx5 and $\mathrm{GH}$ remains undetermined, there exist some interactions or association between them during zebrafish embryogenesis. According to the recent studies, we could reasonably assume that transcription factors, probably including TBX5, may play a role in interacting with the $\mathrm{GH}$ mediator array in the nucleus. For example, GHresponsive transcription factors in sex-specific liver gene expressions are an example of interaction between $\mathrm{GH}$ and transcription factors in specific tissues [44]. Meanwhile, a transcription factor that regulates $\mathrm{GH}$-variant gene expression could also exist [45]. On the other hand, the latest investigation declared, the transcription factor STAT3 (signal transducer and activator of transcription 3 ), one of downstream signaling molecules for $\mathrm{GH}$, directly control the expression of tbx 5 in P19CL6 cells for cardiomyocyte differentiation [46]. The conclusion not only points out a connection between GH and TBX5 transcription factor, but also implies that $\mathrm{GH}$ might activate and increase $t b x 5$ expression in $t b \times 5$ morphants. That is, GH compensates the deficiency of TBX5 via STAT3 and other transcriptional factors and maintains the $t b \times 5$-associated cascade effects of organogenesis and morphogenesis in early embryonic stages, partially.

Though GH is generally considered to be an endocrine factor because it is primarily synthesized by pituitary somatotrophs and is secreted into the circulation. However, it has been clear that GH is produced in many tissues outside the pituitary gland and acts as a local or maternal growth factor in the autocrine/paracrine regulation of cellular differentiation during embryonic and fetal development [22,47]. Because the growth effect occurs prior to differentiation of pituitary somatotrophs, early embryonic growth is independent of pituitary GH. Prinzio et al. announces the distribution and expression of growth hormone receptors, ghra and ghrb, in embryonic zebrafish by means of RT-PCR and whole mount in situ hybridization, and the genomic organization by cloning and sequence analysis [32]. They prove ghra and ghrb expression was detected at all stages entail maternal origin [32]. It is undeniable that maternal GH did play a role in early embryonic development of zebrafish; and it is taken for granted that blockage of $\mathrm{GH}$ directly interferes with normal cardiac development and even induces cardiac malformation and dysfunction [48]. If we hypothesized that Tbx5 may play a role in interaction with maternal/local $\mathrm{GH}$ and in the activation of cascade $\mathrm{GH}$ signaling in early embryonic development to assist the chronological organogenesis. Then it is reasonable that the normal physical responses to maternal $\mathrm{GH}$ in embryonic zebrafish development is decreased after knockdown of tbx5, and the responses could be reinforced by extra supplement of passable exogenous $\mathrm{GH}$.

Phosphorylation that is mediated by PI3K-AKT and MAPK signaling cascades is an important component of the acting mechanism of local GH-stimulated transcription at the organogenesis phase [49-51]. Our results suggest that the local $\mathrm{GH}$ pathway acts similarly to the conventional GH/IGF-1 signaling pathway [48,52-54] and that exogenous $\mathrm{GH}$ activates Akt and Erk pathways in the nucleus, probably by binding to local insulin receptors. Local GH signaling downstream of the P13KAKT system is a key effect related to regulation of cell survival and mRNA translation, while signaling downstream of the MAPK-ERK system involves regulating cellular proliferation. This suggests that exogenous GH signaling occurs via local GH receptors during heart looping formation and chamber maturation stages.

We established four control groups in order to verify the specific $\mathrm{GH}$ effects without interference of morpholino and technical influences of micro-injection. However, interesting phenomena were disclosed by careful interpretation among those different control groups. First, igf1 transiently surged in zebrafish embryos injected by missense morpholino (MISMO group) without subsequent effects, but the phenomenon didn't happen in the expressions of ghra, ghrb, erk1, and akt2. It may aggressively assume that $\mathrm{GH}$ effects may involve IGF-1 dependent and independent pathways in embryonic development to switch on the cascade reactions. Thus the role of IGF-1 attracts attention for further exploration. Moreover, the expressions of ghra and ghrb in WTGH group significantly increased than MOGH group, but the expressions of erk1, akt2, amhc, vmhc, cmlc2 in WTGH group had no remarkable change than MOGH group. It implies that excess GH works inefficiently in individuals without tbx 5 deficiency, or GH deficiency. GH receptors could be reactivated and responded to exogenous $\mathrm{GH}$, but downstream signals and cardiomyogenesis-related genes didn't markedly act in response to overload of GH. The results are compatible with the biological functions of $\mathrm{GH}$ in mature adult individuals. Surly, supplementary designs of control groups, for example, such as use of BSA with equivalent amount as a blank control, could be launched to access the authentic GH effects by our experimental model.

Although GH is able to partially restore dysmorphogenesis and cascade gene expressions in $t b \times 5$ morphants, it cannot completely rescue those changes. Proper timing of GH treatment and optimal dosing might be found to enhance its therapeutic capability. Conversely, this approach may be limited by $\mathrm{GH}$ being partially significant to the complex functioning of the $t b x 5$ network or because it compensates for only a small part of the chronological effects of $t b x 5$ deficiency. Additional 
research is required to determine whether it is practicable to introduce GH to mend developmental defects in early embryogenesis.

\section{Conclusions}

In summary, our work provides novel insights into the possible role of $\mathrm{GH}$ in contributing to developmental defects in zebrafish embryos with $t b x 5$ deficiency. We suggest that the functional knockdown of zebrafish $t b \times 5$ results in a failure to develop a complete or functional heart, trunk, and pectoral fins and might be due to a functional GH deficiency induced by the $t b x 5$ deficiency because it is a key factor causing abnormal organogenesis. Exogenous GH experiments in zebrafish embryos with $t b x 5$ deficiency led to the conclusion that intrinsic growth-control mechanisms, including apoptosis, cell cycle, and cardiomyogenesis that control organic growth, depend on local GH and growth factors between cells and their neighbors. They also indicate that these interactions include controlling cardiac loop formation and the development of trunk and pectoral fins. The improvement of abnormal embryonic organogenesis in zebrafish embryos with $t b \times 5$ deficiency by the administration of exogenous $\mathrm{GH}$ suggests its potential application in human congenital anomalies.

\section{Competing interests}

The authors declare that they have no competing interests.

\section{Author details}

${ }^{1}$ Department of Medical Research and Education, National Yang-Ming University Hospital, Yilan, Taiwan, Republic of China. ${ }^{2}$ School of Medicine, National Yang Ming University, Taipei, Taiwan, Republic of China. ${ }^{3}$ Laboratory of Molecular Biology, Institute of Aquaculture, National Taiwan Ocean University, Keelung, Taiwan, Republic of China. ${ }^{4}$ Department of Pediatrics, Taipei Veterans General Hospital, Taipei, Taiwan, Republic of China. ${ }^{5}$ Institute of Zoology, National Taiwan University, Taipei, Taiwan, Republic of China.

\section{Authors' contributions}

$J H L$ and JKL conceived of the study, participated in its design, coordination. TCT participated in its design and drafted the manuscript. SLC and SYY carried out the molecular genetic studies. RBT and HYL participated in its design and coordination. All authors read and approved the final manuscript.

Received: 7 February 2012 Accepted: 9 July 2012

Published: 9 July 2012

\section{References}

1. Basson CT, Bachinsky DR, Lin RC, Levi T, Elkins JA, Soults J, Grayzel D, Kroumpouzou E, Traill TA, Leblanc-Straceski J, Renault B, Kucherlapati R, Seidman JG, Seidman CE: Mutations in human TBX5 cause limb and cardiac malformation in Holt-Oram syndrome. Nat Genet 1997, 15:30-35.

2. Li QY, Newbury-Ecob RA, Terrett JA, Wilson DI, Curtis AR, Yi CH, Gebuhr T, Bullen PJ, Robson SC, Strachan T, Bonnet D, Lyonnet S, Young ID, Raeburn $J A$, Buckler AJ, Law DJ, Brook JD: Holt-Oram syndrome is caused by mutations in TBX5, a member of the Brachyury (T) gene family. Nat Genet 1997, 15:21-29.

3. Hatcher CJ, Diman NY, Kim MS, Pennisi D, Song Y, Goldstein MM, Mikawa T, Basson CT: A role for Tbx5 in proepicardial cell migration during cardiogenesis. Physiol Genomics 2004, 18:129-140.

4. Zhu Y, Song D, Tran NT, Nguyen N: The effects of the members of growth hormone family knockdown in zebrafish development. Gen Comp Endocrinol 2007, 150:395-404
5. Begemann $G$, Ingham PW: Developmental regulation of Tbx5 in zebrafish embryogenesis. Mech Dev 2000, 90:299-304.

6. Garrity DM, Childs S, Fishman MC: The heartstrings mutation in zebrafish causes heart/fin Tbx5 deficiency syndrome. Development 2002, 129:4635-4645.

7. Ahn DG, Kourakis MJ, Rohde LA, Silver LM, Ho RK: T-box gene tbx5 is essential for formation of the pectoral limb bud. Nature 2002, 417:754-758.

8. Ghosh TK, Song FF, Packham EA, Buxton S, Robinson TE, Ronksley J, Self T, Bonser AJ, Brook JD: Physical interaction between TBX5 and MEF2C is required for early heart development. Mol Cell Biol 2009, 29:2205-2218.

9. Lu JH, Lu JK, Choo SL, Li YC, Yeh HW, Shive JF, Yeh VC: Cascade effect of cardiac myogenesis gene expression during cardiac looping in tbx5 knockdown zebrafish embryos. J Biomed Sci 2008, 15:779-787.

10. Bruneau BG, Nemer G, Schmitt JP, Charron F, Robitaille L, Caron S, Conner DA, Gessler M, Nemer M, Seidman CE, Seidman JG: A murine model of Holt-Oram syndrome defines roles of the T-box transcription factor Tbx5 in cardiogenesis and disease. Cell 2001, 106:709-721.

11. Hiroi Y, Kudoh S, Monzen K, Ikeda Y, Yazaki Y, Nagai R, Komuro I: Tbx5 associates with $\mathrm{Nk \times 2-5}$ and synergistically promotes cardiomyocyte differentiation. Nat Genet 2001, 28:276-280.

12. Maitra M, Schluterman MK, Nichols HA, Richardson JA, Lo CW, Srivastava D, Garg V: Interaction of Gata4 and Gata6 with Tbx5 is critical for normal cardiac development. Dev Biol 2009, 326:368-377.

13. Goetz SC, Brown DD, Conlon FL: TBX5 is required for embryonic cardiac cell cycle progression. Development 2006, 133:2575-2584.

14. Lu J, Tsai T, Choo S, Yeh S, Tang R, Yang A, Lee H, Lu J: Induction of apoptosis and inhibition of cell growth by tbx 5 knockdown contribute to dysmorphogenesis in Zebrafish embryos. J Biomed Sci 2011, 18:73-82.

15. Brown DD, Martz SN, Binder O, Goetz SC, Price BM, Smith JC, Conlon FL: Tbx5 and Tbx20 act synergistically to control vertebrate heart morphogenesis. Development 2005, 132:553-563.

16. van den Eijnden MJ, Lahaye LL, Strous GJ: Disulfide bonds determine growth hormone receptor folding, dimerisation and ligand binding. J Cell Sci 2006, 119:3078-3086.

17. Yada T, Azuma T, Takagi Y: Stimulation of non-specific immune functions in seawater-acclimated rainbow trout, Oncorhynchus mykiss, with reference to the role of growth hormone. Comp Biochem Physiol B Biochem Mol Biol 2001, 129:695-701.

18. Rosa CE, Kuradomi RY, Almeida DV, Lannes CF: Figueiredo Mde A, Dytz AG, Fonseca DB, Marins LF: GH overexpression modifies muscle expression of anti-oxidant enzymes and increases spinal curvature of old zebrafish. Exp Gerontol 2010, 45:449-456.

19. Dalla Libera L, Ravara B, Volterrani M, Gobbo V, Della Barbera M, Angelini A, Danieli Betto D, Germinario E, Vescovo G: Beneficial effects of GH/IGF-1 on skeletal muscle atrophy and function in experimental heart failure. $\mathrm{Am} \mathrm{J}$ Physiol Cell Physiol 2004, 286:C138-C144.

20. Gonzalez-Juanatey JR, Pineiro R, Iglesias MJ, Gualillo O, Kelly PA, Diéguez C, Lago F: GH prevents apoptosis in cardiomyocytes cultured in vitro through a calcineurin-dependent mechanism. J Endocrinol 2004, 180:325-335.

21. Liu N, Mertani HC, Norstedt G, Tornell J, Lobie PE: Mode of the autocrine/ paracrine mechanism of growth hormone action. Exp Cell Res 1997, 237:196-206.

22. Pantaleon M, Whiteside EJ, Harvey MB, Barnard RT, Waters MJ, Kaye PL: Functional growth hormone $(\mathrm{GH})$ receptors and $\mathrm{GH}$ are expressed by preimplantation mouse embryos: a role for $\mathrm{GH}$ in early embryogenesis? Proc Natl Acad Sci USA 1997, 94:5125-5130.

23. Schulte-Merker S, Ho RK, Herrmann BG, Nusslein-Volhard C: The protein product of the zebrafish homologue of the mouse $\mathrm{T}$ gene is expressed in nuclei of the germ ring and the notochord of the early embryo. Development 1992, 116:1021-1032.

24. Oxtoby E, Jowett T: Cloning of the zebrafish krox-20 gene (krx-20) and its expression during hindbrain development. Nucleic Acids Res 1993, 21:1087-1095.

25. Hasson $P$, DeLaurier A, Bennett M, Grigorieva E, Naiche LA, Papaioannou VE, Mohun TJ, Logan MP: Tbx4 and tbx5 acting in connective tissue are required for limb muscle and tendon patterning. Dev Cell 2010, 18:148-156. 
26. Hatcher CJ, Kim MS, Mah CS, Goldstein MM, Wong B, Mikawa T, Basson CT: TBX5 transcription factor regulates cell proliferation during cardiogenesis. Dev Biol 2001, 230:177-188.

27. Liberatore $C M$, Searcy-Schrick RD, Yutzey KE: Ventricular expression of tbx5 inhibits normal heart chamber development. Dev Biol 2000, 223:169-180.

28. Plageman TF Jr, Yutzey KE: Differential expression and function of Tbx5 and Tbx20 in cardiac development. J Biol Chem 2004, 279:19026-19034.

29. Rothschild SC, Easley CA 4th, Francescatto L, Lister JA, Garrity DM, Tombes RM: Tbx5-mediated expression of $\mathrm{Ca}(2+) /$ calmodulin-dependent protein kinase II is necessary for zebrafish cardiac and pectoral fin morphogenesis. Dev Biol 2009, 330:175-184

30. Camarata T, Krcmery J, Snyder D, Park S, Topczewski J, Simon HG: Pdlim7 (LMP4) regulation of Tbx5 specifies zebrafish heart atrio-ventricular boundary and valve formation. Dev Biol 2010, 337:233-245.

31. Minguillon C, Gibson-Brown JJ, Logan MP: Tbx4/5 gene duplication and the origin of vertebrate paired appendages. Proc Natl Acad Sci USA 2009, 106:21726-21730

32. Di Prinzio CM, Botta PE, Barriga EH, Ríos EA, Reyes AE, Arranz SE: Growth hormone receptors in zebrafish (Danio rerio): adult and embryonic expression patterns. Gene Expr Patterns 2010, 10:214-225.

33. Li X, He J, Hu W, Yin Z: The essential role of endogenous ghrelin in growth hormone expression during zebrafish adenohypophysis development. Endocrinology 2009, 150:2767-2774

34. Toro S, Wegner J, Muller M, Westerfield M, Varga ZM: Identification of differentially expressed genes in the zebrafish hypothalamic-pituitary axis. Gene Expr Patterns 2009, 9:200-208.

35. Zhou J, Li W, Kamei H, Duan C: Duplication of the IGFBP-2 gene in teleost fish: protein structure and functionality conservation and gene expression divergence. PLOS One 2008, 3:e3926.

36. Butler AA, Le Roith D: Control of growth by the somatropic axis: growth hormone and the insulin-like growth factors have related and independent roles. Annu Rev Physiol 2001, 63:141-164.

37. Ganong WF: Review of medical physiology. Lange Medical Publications 1981, 322:table 22-23.

38. Xu Q: Methods in Molecular Biology, Chapter 11 Microinjection into Zebrafish Embryos. Springer International Publisher 1999, 127:25-132.

39. Lincoln DT, Sinowatz F, Temmim-Baker L, Baker HI, Kölle S, Waters MJ: Growth hormone receptor expression in the nucleus and cytoplasm of normal and neoplastic cells. Histochem Cell Biol 1998, 109:141-159.

40. Nadeau M, Georges RO, Laforest B, Yamak A, Lefebvre C, Beauregard J, Paradis $P$, Bruneau $B G$, Andelfinger $G$, Nemer M: An endocardial pathway involving Tbx5, Gata4, and Nos3 required for atrial septum formation. Proc Natl Acad Sci USA 2010, 107:19356-19361.

41. Eisenhauer KM, Chun SY, Billig H, Hsueh AJ: Growth hormone suppression of apoptosis in preovulatory rat follicles and partial neutralization by insulin-like growth factor binding protein. Biol Reprod 1995, 53:13-20.

42. Stirnimann CU, Ptchelkine D, Grimm C, Muller CW: Structural basis of TBX5-DNA recognition: the T-box domain in its DNA-bound and -unbound form. J Mol Biol 2010, 400:71-81.

43. Waters MJ, Shang CA, Behncken SN, Tam SP, Li H, Shen B, Lobie PE: Growth hormone as a cytokine. Clin Exp Pharmacol Physiol 1999, 26:760-764.

44. Laz EV, Holloway MG, Chen CS, Waxman DJ: Characterization of three growth hormone-responsive transcription factors preferentially expressed in adult female liver. Endocrinology 2007, 148:3327-3337.

45. Lomenick JP, Hubert MA, Handwerger S: Transcription factor FOXF1 regulates growth hormone variant gene expression. Am J Physiol Endocrinol Metab 2006, 291:E947-951.

46. Snyder M, Huang XY, Zhang JJ: Stat3 directly controls the expression of Tbx5, Nkx2.5, and GATA4 and is essential for cardiomyocyte differentiation of P19CL6 cells. J Biol Chem 2010, 285:23639-23646.

47. Harvey S, Johnson CD, Sharma P, Sanders EJ, Hull KL: Growth hormone: a paracrine growth factor in embryonic development? Comp Biochem Physiol C Pharmacol Toxicol Endocrinol 1998, 119:305-315.

48. Bruel A, Christoffersen TE, Nyengaard JR: Growth hormone increases the proliferation of existing cardiac myocytes and the total number of cardiac myocytes in the rat heart. Cardiovasc Res 2007, 76:400-408.

49. DeBosch B, Sambandam N, Weinheimer C, Courtois M, Muslin AJ: Akt2 regulates cardiac metabolism and cardiomyocyte survival. $J$ Biol Chem 2006, 281:32841-32851.

50. Gabillard JC, Duval H, Cauty C, Rescan PY, Weil C: Differential expression of the two GH genes during embryonic development of rainbow trout
Oncorhynchus mykiss in relation with the IGFs system. Mol Reprod Dev 2003, 64:32-40.

51. Murakami Y, Shimizu T, Yamamoto M, Kato Y: Serum levels of 20 kilodalton human growth hormone $(20 \mathrm{~K}-\mathrm{hGH})$ in patients with acromegaly before and after treatment with octreotide and transsphenoidal surgery. Endocr J 2004, 51:343-348.

52. Harvey S, Johnson CD, Sanders EJ: Extra-pituitary growth hormone in peripheral tissues of early chick embryos. J Endocrinol 2000, 166:489-502

53. Joudrey EM, Lechniak D, Petrik J, King WA: Expression of growth hormone and its transcription factor, Pit-1, in early bovine development. Mol Reprod 2003, 64:275-283.

54. Thatcher WW, Guzeloglu A, Meikle A, Kamimura S, Bilby T, Kowalski AA, Badinga L, Pershing R, Bartolome J, Santos JE: Regulation of embryo survival in cattle. Reprod Supp/ 2003, 61:253-266.

doi:10.1186/1423-0127-19-63

Cite this article as: Tsai et al:: The paracrine effect of exogenous growth hormone alleviates dysmorphogenesis caused by $t b \times 5$ deficiency in zebrafish (Danio rerio) embryos. Journal of Biomedical Science 2012 19:63.

\section{Submit your next manuscript to BioMed Central and take full advantage of:}

- Convenient online submission

- Thorough peer review

- No space constraints or color figure charges

- Immediate publication on acceptance

- Inclusion in PubMed, CAS, Scopus and Google Scholar

- Research which is freely available for redistribution

Submit your manuscript at www.biomedcentral.com/submit
C Biomed Central 